\title{
LANGUAGE LEARNING STRATEGIES USED BY EFL FLUENT SPEAKERS: A CASE IN INDONESIAN CONTEXT
}

\author{
M. Ali Ghufron \\ Email: alghufron.87@gmail.com \\ English Education Department of IKIP PGRI Bojonegoro \\ Bojonegoro, Indonesia
}

\begin{abstract}
This study reported what language learning strategies are used by EFL fluent speakers in EFL speaking class and to reveal the fluent speakers' awareness of the benefits of the language learning strategies. This research was conducted on six students in EFL Speaking Class of English Education Department of IKIP PGRI Bojonegoro, Indonesia, who were categorized as EFL fluent speakers. The research belongs to a case study. The data for this research were taken from indepth interviews, observation, filling up questionnaires, and document analysis. The results of this study show that 1) in EFL sepaking class, the $1^{\text {st }}$ student used cognitive, compensation, and social strategies, the $2^{\text {nd }}$ student used cognitive and affective strategies, the $3^{\text {rd }}$ student used cognitive, meta-cognitive and social strategies, the $4^{\text {th }}$ student used meta-cognitive and social strategies, the $5^{\text {th }}$ student used cognitive and affective strategies, and the $6^{\text {th }}$ student used meta-cognitive and social strategies. 2) The students are strongly aware of the learning strategies' benefits to improve their English skills. From the findings, it can be concluded that learning strategies are very useful and helpful in learning English as a foreign language. Learning strategies also bring the students reach the good achievement in improving their speaking skill.
\end{abstract}

Keywords: EFL fluent speakers, language learning strategies, (meta)cognitive strategy, affective strategy, compensation strategy, social strategy, memory strategy.

\section{INTRODUCTION}

Speaking plays an important role in making a communication or a social interaction with another people in order to gain information orally. So, it is needed for every people to have a good speaking skill. Byrne (1986) says that speaking skill covers practice and production stage. The practice stage concerns on accuracy that focuses on the 
elements of phonology, grammar, and discourse in spoken output. The production stage concerns on speaking fluency. It means that learners who have passed the practice stage are demanded to continue to the production stage.

Speaking fluency is an aspect of oral communication to express the human idea, feeling, opinion and thought or information which helps people to communicate one another without hesitation, repetition, and a false start. According to Fillmore (1979), speaking fluency is the ability to fill time with talk, to talk without significant pauses for an extended period. He also adds that fluency is the ability to be creative and imaginative in language use, including joking, varying styles, creating metaphors, etc. It can be assumed that fluency is the ability in which the students to speak without significant pauses and has a creative and imaginative thinking. According to Thornbury (2005, p. 8 ), the features of fluency are: Pauses may be long but not frequented, pauses are usually filled, pauses occur at meaningful transition points, there are long runs of syllable and word between pause. To be able to speak using English as a foreign language fluently and accurately, they need great mental and physical effort. This is because to be able to speak fluently, the language learners have to speak and think at the same time

Foreign language/L2 learners are totally different with native speakers. Their culture and mother tongue which determine speaking skill is different. So, to be able to speak English fluently L2 learners have to have serious efforts. They have to study hard, practice more often and intensively and use appropriate learning strategy and suitable for them.

Learning strategy is a certain way which students use in order to comprehend certain material and improve their learning (Oxford, 1990). Oxford (1990, p. 8) mentions more specifically that learning strategies are any possible actions chosen by the learners to comprehend something and create more enjoyable and easier way of learning. Lee (2010, p. 134-135) adds, "When learners start to learn something, they have the ability to respond to the particular learning situation and to manage their learning in an appropriate way. Learners use learning strategies in order to learn something more successfully". 
Based on the researcher's investigation in every class of English Education Department, there are just two until three students who can speak English fluently each class. Moreover, even they have studied four years in English Department; only a few of them can speak English fluently. Those facts have been a big question for the researcher to investigate the learning strategies of fluent speakers. The researcher hopes the results of this research can be used by all EFL students to improve their speaking fluency.

In this research, the researcher investigated the learning strategies used by EFL fluent speakers in English speaking class to get an understanding of how the fluent speakers learn English. Therefore, the researcher conducted a qualitative research study to investigate and observe their learning strategy.

Based on the rationale above, the questions in this research are formulated as follows: (1) what learning strategies do EFL fluent speakers use in English speaking class? and (2) to what extent are EFL fluent speakers aware of the benefits of the learning strategies?

\section{LANGUAGE LEARNING STRATEGIES}

There have been numerous researches focused on language learning strategies. The latest research done by Griffiths \& Oxford (2014), they introduced the global reach and roadmap of language learning strategies in the twenty-first century - a panoramic view of the international landscape of strategies. There are eight key areas of controversy and discussion: strategy definitions, strategies and proficiency, theoretical underpinnings, categorization, context, teachability, research methodology, and analysis. Those areas, later on, will be the new issues to be discussed in research focusing on language learning strategies.

O'Malley and Chamot (1990, p. 1) illustrated learning strategies as special thoughts or behaviors that individuals use to help them comprehend, learn, or retain new information. Learning strategies are intentional behavior and thoughts that learners make use of during learning in order to better help them understand, learn, or remember new information (Richards, Platt and Platt, 1992; Zare, 2012). Wenden and Rubin (1987) describe learning strategies as any 
sets of operations, steps, plans, routines used by the learner to facilitate the obtaining, storage, retrieval, and use of information.

The strategy that students use for their learning is also included as the factor to determine how well students learn language (Oxford, 2003, p.1). Lee (2010, p. 132) states the aim of using learning strategies by learners is to learn something more successfully. Students who have their appropriate learning strategies normally will have better understanding. Moreover, Oxford (1990, p. 8) states that learning strategies help to make the learning becomes easier, faster, more enjoyable, more self-directed, more effective, and more transferrable to new situation. Their better understanding will result good marks in their learning.

Self-report is the only way to dig up students' learning strategies (Chamot, 2004). However, self-report can be less accurate source if the learners do not report truthfully. Therefore, when a researcher wants to reveal learners' learning strategies, he/she need to be careful when collecting the related information to the learners. By doing so, it is hoped that the researcher will get more accurate data.

From the theories above, learning strategies can be constructed as learning tools which selected by learners to help them successful in the learning process. Moreover, the learning strategies have to make the learning easier, faster, and more enjoyable.

\section{THE CLASSIFICATION OF LANGUAGE LEARNING STRATEGIES}

Language learning strategies have been classified by many researchers. However, the classifications of language learning strategies are more or less the same. Oxford (1990, p. 12-17) classified into two big types of language learning strategies; direct and indirect, which are further categorized into six groups. Direct strategies are strategies used by learners by involving the new language directly for example: guessing meaning of the target language, producing sentences using the target language, etc. These strategies require mental processing of the language such as memory strategies, cognitive strategies and compensation strategies. Meanwhile, indirect strategies are strategies that support and manage language learning without directly involving 
the target language such as metacognitive strategies, affective strategies and social strategies.

Table 1. The Classification of Language Learning Strategies by Oxford (1990)

\begin{tabular}{|c|c|c|}
\hline CLASS & GROUP & SET \\
\hline \multirow[t]{10}{*}{ Direct Strategies } & \multirow{4}{*}{$\begin{array}{l}\text { Memory } \\
\text { Strategies }\end{array}$} & Creating mental linkages \\
\hline & & Applying images and sounds \\
\hline & & Reviewing well \\
\hline & & Employing action \\
\hline & \multirow{4}{*}{$\begin{array}{l}\text { Cognitive } \\
\text { Strategies }\end{array}$} & Practicing \\
\hline & & $\begin{array}{l}\text { Receiving and sending } \\
\text { messages }\end{array}$ \\
\hline & & Analyzing and reasoning \\
\hline & & $\begin{array}{l}\text { Creating structure for input } \\
\text { and output }\end{array}$ \\
\hline & \multirow[t]{2}{*}{$\begin{array}{l}\text { Compensation } \\
\text { Strategies }\end{array}$} & $\begin{array}{l}\text { Guessing } \\
\text { Intelligently }\end{array}$ \\
\hline & & $\begin{array}{l}\text { Overcoming limitations in } \\
\text { speaking and writing }\end{array}$ \\
\hline \multirow[t]{9}{*}{ Indirect Strategies } & \multirow{3}{*}{$\begin{array}{l}\text { Metacognitive } \\
\text { Strategies }\end{array}$} & Centering your learning \\
\hline & & $\begin{array}{l}\text { Arranging and planning your } \\
\text { learning }\end{array}$ \\
\hline & & Evaluating your learning \\
\hline & \multirow{3}{*}{$\begin{array}{l}\text { Affective } \\
\text { strategies }\end{array}$} & Lowering your anxiety \\
\hline & & Encouraging yourself \\
\hline & & $\begin{array}{l}\text { Taking your emotional } \\
\text { temperature }\end{array}$ \\
\hline & \multirow[t]{3}{*}{ Social strategies } & Asking questions \\
\hline & & Cooperating with others \\
\hline & & Empathizing with others \\
\hline
\end{tabular}

O’Malley and Chamot (1990, p. 45) suggest that language learning strategies can be divided into three groups: metacognitive strategies, cognitive strategies, and social/ affective strategies. This differentiation depends on the level or type of processing involved. O'Malley and Chamot (1990), define metacognitive strategies as skills that may entail planning for, monitoring, or evaluating the success of a 
learning activity. Then, they suggest that cognitive strategies refer to activities learners use to obtain, store, retrieve, and use language information. The last, socio-affective strategies are defined as activities that involve either interaction with another person or ideational control over affectation.

Table 2. The Classification of Language Learning Strategies by O'Malley \& Chamot (1990)

\begin{tabular}{|l|l|l|}
\hline $\begin{array}{c}\text { Generic } \\
\text { strategy } \\
\text { classification }\end{array}$ & $\begin{array}{l}\text { Representative } \\
\text { strategies }\end{array}$ & \multicolumn{1}{|c|}{ Definitions } \\
\hline Metacognitive & $\begin{array}{l}\text { Selective } \\
\text { attention }\end{array}$ & $\begin{array}{l}\text { Focusing on special aspects of } \\
\text { learning tasks, as in planning to } \\
\text { listen for key words or phrases }\end{array}$ \\
\cline { 2 - 3 } & Planning & $\begin{array}{l}\text { Planning for the organization of } \\
\text { either written or spoken discourse }\end{array}$ \\
\cline { 2 - 4 } & Monitoring & $\begin{array}{l}\text { Reviewing attention to a task, } \\
\text { comprehension of information that } \\
\text { should be remembered, or } \\
\text { production while it is occurring }\end{array}$ \\
\cline { 2 - 4 } & Evaluation & $\begin{array}{l}\text { Checking comprehension after } \\
\text { completion of a receptive a } \\
\text { receptive language activity, or } \\
\text { evaluating language production } \\
\text { after it has taken place }\end{array}$ \\
\hline Cognitive & Rehearsal & $\begin{array}{l}\text { Repeating the names of items or } \\
\text { objects to be remembered }\end{array}$ \\
\cline { 2 - 4 } & Organization & $\begin{array}{l}\text { Grouping and classifying words, } \\
\text { terminology, or concepts according } \\
\text { to their semantic or syntactic } \\
\text { attributes }\end{array}$ \\
\cline { 2 - 4 } & Summarizing & $\begin{array}{l}\text { Using information in text to guess } \\
\text { meaning of new linguistic items, } \\
\text { predict outcomes, or complete } \\
\text { missing parts }\end{array}$ \\
$\begin{array}{l}\text { Intermittently synthesizing what } \\
\text { one has heard to ensure the } \\
\text { information has been retained }\end{array}$ \\
\hline
\end{tabular}




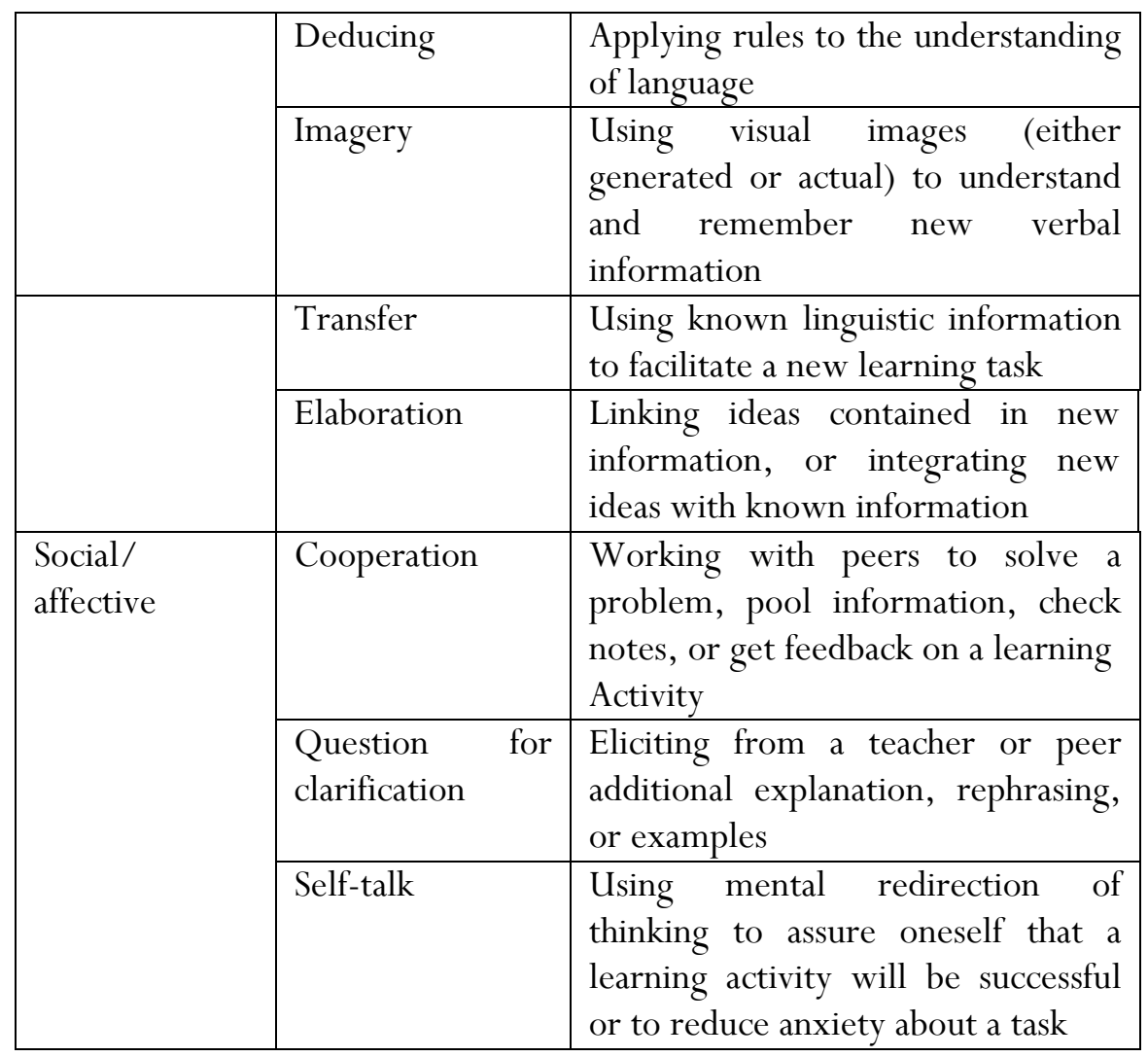

\section{SPEAKING FLUENCY}

\section{Fluency}

Fluency in speaking is one of the competencies targeted by many language learners. Signs of fluency include a reasonably fast speed of speaking and only a small numbers of pauses and filters. Byrne (1986) states that speaking fluency as the ability to express oneself intelligibly reasonably accurately and without too much hesitation. These indicate that speaker does not have to spend a lot of time searching for the language items needed to express the message. A fluent speaker is able to express his idea accurately and fluently.

According to Fillmore (1979), speaking fluency is the ability to fill time with talk, to talk without significant pauses for an extended period". He also adds that fluency is the ability to be creative and imaginative in language use, including joking, varying styles, creating metaphors, etc. It can be assumed that fluency is the ability in which 
the students to speak without significant pauses and has a creative and imaginative thinking.

Gower, Philips, and Walters (1995) state that speaking fluency as the ability to keep going when speaking spontaneously. It means that the speaker can be called fluent speaker if he or she can speak smoothly without broken off from the beginning until the end of the speech.

From the definition above, it can be concluded that speaking fluency is the ability to produce and use meaningful language effectively without significant pauses and hesitation, and also the ability in which speaker to be creative and imaginative in using language.

\section{Aspects of Fluency}

Pearson Education, Inc (2005) describes fluency scoring in Table 3, as follows.

\section{Table 3. Fluency Scoring by Pearson Education, Inc (2005)}

\begin{tabular}{|l|l|}
\hline Rating & Demonstrated competence \\
\hline 4 & $\begin{array}{l}\text { Uses a variety of vocabulary and expressions } \\
\text { Uses a variety of structures with only occasional grammatical } \\
\text { errors } \\
\text { Speaks smoothly, with little hesitation that does not interfere } \\
\text { with communication } \\
\text { Stays on task and communicates effectively; almost always } \\
\text { responds appropriately and always tries to develop the } \\
\text { interaction } \\
\text { Pronunciation and intonation are almost always very } \\
\text { clear/accurate }\end{array}$ \\
\hline 3 \\
$\begin{array}{l}\text { Uses a variety of vocabulary and expressions, but makes some } \\
\text { errors in word choice } \\
\text { Uses a variety of grammar structures, but makes some errors } \\
\text { Speaks with some hesitation, but it does not usually interfere } \\
\text { with communication } \\
\text { Stays on task most of the time and communicates effectively; } \\
\text { generally responds appropriately and keeps trying to develop } \\
\text { the interaction } \\
\text { Pronunciation and intonation are usually clear/accurate with } \\
\text { a few problem areas }\end{array}$ \\
\hline
\end{tabular}




\begin{tabular}{|c|c|}
\hline 2 & $\begin{array}{l}\text { Uses limited vocabulary and expressions } \\
\text { Uses a variety of structures with frequent errors, or uses basic } \\
\text { structures with only occasional errors } \\
\text { Speaks with some hesitation, which often interferes with } \\
\text { communication } \\
\text { Tries to communicate, but sometimes does not respond } \\
\text { appropriately or clearly } \\
\text { Pronunciation and intonation errors sometimes make it } \\
\text { difficult to understand the student }\end{array}$ \\
\hline 1 & $\begin{array}{l}\text { Uses only basic vocabulary and expressions } \\
\text { Uses basic structures, makes frequent errors } \\
\text { Hesitates too often when speaking, which often interferes } \\
\text { with communication } \\
\text { Purpose isn't clear; needs a lot of help communicating; } \\
\text { usually does not respond appropriately or clearly } \\
\text { Frequent problems with pronunciation and intonation }\end{array}$ \\
\hline
\end{tabular}

British Council also describes fluency scoring in IELTS speaking band descriptors clearly. The highest score (9 scores) are: speaks fluently with only rare repetition or self-correction (any hesitation is content-related rather than to find words or grammar), speaks coherently with fully appropriate cohesive features, develops topics fully and appropriately.

Based on the scorings above, it can be concluded that fluency has some aspects. They are smoothness, hesitation, the variety of vocabulary, the variety of expression, the variety of structure, effectiveness (to communicate thoughts), appropriateness (respond and topic development), repetition or self-correction, and coherence.

\section{METHOD}

This case study was conducted in English speaking class of the second year English Education Department students of IKIP PGRI Bojonegoro, Indonesia. This research was focused to investigate learning strategies of EFL fluent speakers and their awareness of learning strategies benefits. Sources of data needed by the researcher were the phenomena of fluent speakers' learning activities which would be in form of field notes, learning strategy questionnaires, interview 
transcripts and documents which was in form of scores transcript. Those data were used for investigating the fluent speakers and after that, the researcher analyzed the data, so the result and conclusion of this research could be drawn.

The researcher used the interactive model of data analysis in analyzing the data. The components of data analysis are data collection, data reduction, data display, and drawing conclusion (Miles \& Huberman, 1994).

Data was collected by conducting observations, interview, giving questionnaire and document analysis. The data collected from observations were about performance and characteristics in the class during teaching and learning activities. Next, the researcher conducted interview with the fluent speakers about their problem and learning strategies, with their friends and their teachers about fluent speakers' characteristics and their learning achievement. The fluent speakers were given questionnaires to be fulfilled to know about their learning strategies and awareness of learning strategies use.

The researcher used the information from the field notes, questionnaires and interview transcript to get fluent speakers' learning strategy and awareness of learning strategies use backgrounds. The researcher describes data reduction as a form of analysis that sharpens, sorts, focuses, discards, and organizes the data in such a way that "final" conclusion can be drawn and verified.

In this research, the data display was done based on the table description of data reduction. The researcher described and discussed the fluent speakers' background of learning problems, learning strategies, and their awareness of learning strategies' benefits.

The researcher decides what things mean by making the conclusion based on the data. The conclusion was drawn based on the result of data analyzing which was about the fluent speakers' characteristics, such as the background of learning problems, learning strategies, and awareness of learning strategies' benefits. The researcher described the most important parts of their learning strategies and their awareness of learning strategies' benefits as the conclusion. Besides, the researcher used triangulation, i.e. member checking to validate the data. 


\section{FINDINGS AND DISCUSSIONS Fluent Speakers' Learning Strategies}

The following is the summary of students' learning strategy:

Table 4. Student Learning Strategies Summary

\begin{tabular}{|l|l|l|}
\hline \multicolumn{1}{|c|}{ Students } & \multicolumn{1}{|c|}{ Profile } & \multicolumn{1}{c|}{$\begin{array}{c}\text { Learning } \\
\text { Strategies }\end{array}$} \\
\hline Student 1 & $\begin{array}{l}\text { Male } \\
23 \text { years old } \\
\text { English 2A }\end{array}$ & $\begin{array}{l}\text { Cognitive } \\
\text { Compensation } \\
\text { Social }\end{array}$ \\
\hline Student 2 & $\begin{array}{l}\text { Female } \\
\text { 20 years old } \\
\text { English 2A }\end{array}$ & $\begin{array}{l}\text { Cognitive } \\
\text { Affective }\end{array}$ \\
\hline Student 3 & $\begin{array}{l}\text { Female } \\
22 \text { years old } \\
\text { English 2A }\end{array}$ & $\begin{array}{l}\text { Cognitive } \\
\text { Metacognitive } \\
\text { Social }\end{array}$ \\
\hline Student 4 & $\begin{array}{l}\text { Female } \\
\text { 25 years old } \\
\text { English 2B }\end{array}$ & $\begin{array}{l}\text { Metacognitive } \\
\text { Social }\end{array}$ \\
\hline Student 5 & $\begin{array}{l}\text { Female } \\
\text { 20 years old } \\
\text { English 2B }\end{array}$ & $\begin{array}{l}\text { Cognitive } \\
\text { Affective }\end{array}$ \\
\hline Student 6 & $\begin{array}{l}\text { Female } \\
\text { 25 years old } \\
\text { English 2B }\end{array}$ & $\begin{array}{l}\text { Metacognitive } \\
\text { Social }\end{array}$ \\
& \multicolumn{2}{|l}{} \\
\hline
\end{tabular}

\section{Fluent Speakers' Awareness of the Benefits of the Learning Strategies}

Student 1 was the only man in this research. Actually he had different behavior with woman in the learning activities. And of course he was the most fluent man of the second graders. He was included students who could feel how the English language learning strategies affect achievement of English fluency in the classroom well. In applying learning strategies, student 1 surely felt the important of learning strategies.

He felt that learning strategies were needed in order to improve English fluency. Learning strategy by made schedule to study regularly 
influenced his learning to be better. It made improvement in English fluency.

He also felt that his fluency improved gradually after used learning strategies. Step by step his speaking skill especially his fluency improved. So, he always used learning strategies in the learning process to get an improvement of English skill especially English fluency.

Related to the influence of learning strategies to fluency improvement, he agreed that learning strategies which he applied had positive influence to his English fluency improvement. He applied 10 vocabularies everyday to enrich his knowledge of vocabulary. It was important to improve his English fluency, because without enlarged vocabulary he could not speak fluently. He was strongly aware of the learning strategies' benefits to improve his English fluency.

Learning strategies of student 2 were highly influential on student achievement. Student achievement was obtained when using learning strategies. The indicator of success in improving English fluency is when the student could speak fluently. Researcher asked about the influence of applying learning strategies to improve her English fluency.

Student 3's learning strategies influenced to the improvement of her English fluency. Related to the affective strategies that student 2 used, this student's skill would easier to be improved if the learning condition was comfortable. After used learning strategies, this student got an improvement of pronunciation and enriched vocabulary. She also explained about the important of using learning strategies to improve English fluency.

She believed that learning strategies was important and needed to improve her English fluency. With learning strategies, her learning method could be more discipline. She also got more comfortable condition to study by using proper learning strategies. Learning strategies became the ways of this student to improve English fluency. She was completely aware of the learning strategies' benefits to improve her English fluency.

Student 3 was the most fluent student of second graders. She was the winner of English Speech Contest. This good learner always used learning strategies to get good improvement in English fluency. 
This student convinced that study language needed some strategies to have good learning.

The researcher asked this student about her learning strategies to improve English fluency. This student explained that learning English as a foreign language required learning strategies because learning strategies were the best way to achieve learning targets or goals that she wanted. Learning strategies were the ways to get good learning but not all of students used good learning strategies in improving English fluency. Just several students used good learning strategies to improve their English fluency.

Student 3 also explained that learning strategies that she used were influencing her improvement of English fluency. Learning strategies were the main thing for her to achieve the target of fluency improvement that she wanted. She explained her improvement of English fluency after used learning strategies reached 75\% from previously $20 \%$. She was aware of learning strategies' benefits in order to improve her English fluency.

Student 4 was very enthusiastic in learning at school, especially when speaking course took place. She assumed that each lesson that she followed must have right learning strategies so that the material presented by the teacher could be well received. Learning strategies were needed by everyone, especially the students while at school. Learn foreign language especially English would require specific strategies so that students could receive and understand well.

Student 4 was sure that she needed right learning strategies to improve her English fluency. She believed that each student has a different understanding with others. So, they must use different learning strategies to improve their speaking fluency. By studying English with proper learning strategies, student 4' English fluency also more increased. She found that it was easier to understand the lessons that lecturers gave to her.

Student 4 also felt that learning strategies she used were influencing her English fluency improvement. By use music and movie, she could memorize new vocabularies easily. She could also understand sentences better. It means that learning strategies gave positive benefits 
to her English fluency. She was aware of those benefits so that she used learning strategies to improve her English fluency.

This student 5 was included a student who was not very active in teaching and learning activities, but she had good fluency of speaking English so that teacher assumed that student 5 as a fluent speaker. Related to this student's learning strategies that tended to cognitive strategies, she improved her English fluency by practicing more and often.

She believed that to improve English fluency she needs good learning strategies. She improved her English fluency by practicing English in speaking. She got a good improvement because of using learning strategies to improve her English fluency. She also explained the influence of her learning strategies to her fluency improvement.

Student 5's learning strategies had a good influence to her English fluency. She used learning strategies to know how to remembering and improving her English fluency. She was aware the benefits of the learning strategies. So, she always used learning strategies to improve her English fluency.

Researcher asked about learning a foreign language required a specific strategy. Each lesson definitely needed a strategy to study this subject because of good learning strategies student could easily understand the lesson. Each student must have a view about learning a foreign language, there were students who used learning strategies and there were students who do not use learning strategies.

Some of the students in the class sometimes used learning strategies to improve their English fluency, but some the students did not know how to use learning strategies properly. Student 6 was very confident in applying learning strategies when English lesson took place in the classroom.

According to student 6, learning strategies were needed to improve English fluency. Every learner had learning strategies which had to be adjusted in line with their absorbing ability of what they learned. So, learning strategies were very important to improve her fluency. She also explained that learning strategies she used were influencing her skill in order to improve English fluency. 
Student 6 added that learning strategies had enough effect to her English fluency improvement. She used learning strategies that comfortable to her learning manner. And it gave positive effect to her improvement of English fluency. She was aware of the learning strategies' benefits to her English fluency improvement.

\section{DISCUSSION}

Learning strategies are believed to be responsible for successful language acquisition and a significant determinant of ultimate success in language learning. Thus, in learning English as a foreign language, good language learning strategies are important as well. Learning strategies are deliberate action taken by language learners to make learning more effective. There are some important things about learning strategies for learners.

The first is learners may become more confident and better in learning to improve their English fluency. Fluent speakers' learning strategies should be recognized and used by other English foreign language learners because by recognizing as well as using fluent speakers' learning strategies, other English learners may become more confident and better in learning to improve their English fluency. The other learners may gain success to improve their English fluency accordingly. It is in accordance with Brown (2003) who states that one of the factors contributing to the success of foreign language learning is the role of the learner in the process" that is recognizing and using good language learning strategies.

The second is that some language learners are more fluent than others. The researcher has all observed that some students approach the language learning task in more successful than others in learning a foreign language. The learning strategy literature said that some of this success can be attributed to particular sets of cognitive and metacognitive behaviors which learners engage in. It is assumed that fluent speakers will differ to some extent in the particular sets of cognitive processes and behaviors which they use to enable them to be fluent. For example, given the same learning environment, the same target language, the same native language, and the same language level, 
some learners' fluency will be more improved while others will get no improvement.

The third is that the students can make learning consciously. Consciousness raising is not incidental to learning. It can be said that making learning decisions conscious can lead both poorer and better to improve the obtaining, storing, retrieving and using of information, that is, can lead them to learn better. Not all learners do their best by approaching the learning task through an intuitive, subconscious, natural process. For example, although debating class is useful to improve English fluency if they are not explained many students never see the relationship of debating class' benefits to improve their speaking ability especially in improving English fluency.

The fourth is that the students understand learning process includes both explicit and implicit knowledge. Research into learning strategies revealed that both explicit and implicit knowledge can contribute to learning (the process of obtaining or getting, storing, retrieving, and using information). For some learners and for some tasks, it is assumed that conscious attention to the learning process is the first step to making language automatic. For example, although students did not understand what another said, they could answer and gave feedback by guessing and read the opponent' mime and gesture. It's very useful when the conversation took place.

The fifth is that fluent speakers' strategies can be used to get good effects by less fluent speakers. Once the strategies of fluent speakers are identified, they can be made available and useful to be used by less fluent speakers to enable them to learn a second/foreign language more effectively. The teacher can promote strategy uses.

The sixth is that students are being active in language learning. Most learning theorists would agree that learning is best achieved when the students play an active role in the process. Being active means that students cannot just be given information, rather they must have opportunities to internalize information in ways which are meaningful to them. Teachers have to give many opportunities for students to speak more in the class. Being active also means that students are faced with problem-solving activities in order to internalize information and to practice more often 
The seventh is that the success of learner training in other subjects is applicable to language learning especially to improve English fluency. Some researches indicated that evidence is accumulating to suggest that an ideal training package would consist of both practices in the use of task-appropriate strategies, instruction concerning the significance of those activities and instruction concerning the monitoring and controlling of strategy use. Since similar kinds of strategies are being isolated for language learning, it is assumed that similar kinds of learning training would be effective in the task of improving English fluency.

The eighth is that the students have critical skill in communicating. Morrison and Low (1983) argue that human language use depends on both creative and critical faculties. Further, they said that the creative faculty operates beyond the back edge of consciousness and is therefore essentially unruly. The critical faculty, which is essentially our awareness or language, gives a lease to the creative faculty, keeps it in check and possibly learns from it. So, firstly students have to train and improve their English fluency continuously and diligently (critical skill). Then, they will be able to speak fluently and automatically (creative skill).

The ninth is that improving English fluency as foreign language needs learners' awareness. Fluent speakers' fluency has improved because of they are strongly aware of the benefits of their learning strategies. This is totally different with native speakers who do not need this awareness of language learning strategies. They learn unconsciously from the child. But foreign learners need high consciousness to improve their English fluency.

\section{CONCLUSION}

To improve English fluency, every student has their own learning strategies as shown in the table of learning strategies summary above. But the most frequently used language learning strategies overall by those six fluent speakers are cognitive and social strategies. And for the students' awareness of the learning strategies benefits, the students are strongly aware of the learning strategies' benefits to improve their English fluency 
Learning strategies of the students are very useful and helpful in learning English as a foreign language. Language learning strategies also bring the students reach the good achievement in improving their English fluency and their academic lesson especially English as a foreign language. Learning strategies are believed to be responsible for successful language acquisition and a significant determinant of ultimate success in language learning. Thus, in learning English as a foreign language, good language learning strategies are important as well.

There are some ideas intended for other researchers that are interested in doing research in the same area, teachers, and curriculum makers. (1) Lecturers should know students' language learning strategies so they can provide and create materials as well as opportunities that fit the students' language learning strategies. (2) Students need to be taught language learning strategies to be able to learn English more effectively. (3) The lecturers can use this research's findings to create a good learning environment in order to improve students' fluency. (4) English lecturers should develop English learning strategies to make students' fluency more improved. (5) Students should aware of the benefits of the learning strategies to get good improvement in English fluency. (6) Students can use this research's finding to get successful in order to improve English fluency. (7) Students should always search the best learning strategy to improve English fluency to keep up to date in this information age. (8) The curriculum should accommodate students' language learning strategies for students' better achievement in learning English.

\section{REFERENCES}

Brown, H. D. (2003). Teaching by principles: an interactive approach to language pedagogy. Second Edition. New York: Longman Inc.

Byrne, D. (1986). Teaching oral english. London: Longman.

Chamot, A. U. (2004). Issues in language learning strategy research and teaching. Electronic Journal of Foreign Language Teaching ,Vol. 1, No. 1, 14-26.

Fillmore, C. J. (1979). On fluency. In Fillmore, C.J., Kempler, D., \& Wang, W. S.-J., (eds), Individual differences in language ability and language behavior. New York: Academic Press. 
Gower, R., Phillips, D., \& Walters, S. (1995). Teaching practice handbook. Oxford: MacMillan Education.

Griffiths, C. \& Oxford, R. (2014). Twenty-first century landscape of language learning strategies. System, 43, 1-10. DOI: 10.1016/j.system.2013.12.009

Lee, C. K. (2010). An overview of language learning strategies. ARECLS: Vol.7, 132-152.

Miles, M. B. \& Huberman, A. M. (1994). An expanded sourcebook: qualitative data analysis (2nd Ed.). Thousand Oaks: Sage.

Morrison, D., \& Low, G. (1983). Monitoring and the second language learner. In J. C., Richards \& R.W., Schmidt (Eds.), Language and communication (pp. 228-250). London: Longman.

Oxford, L. Rebecca. (1990). Language learning strategies: what every teacher should know. New York: Newbury House.

Oxford, R. L. (2003). Language learning styles and strategies: an overview. Learning Styles \& Strategies/ Oxford, GALA, 1-25.

O’Malley, J. M. \& Chamot, A. U. (1990). Learning strategies in second language acquisition. New York: Cambridge University Press.

Richards, J. C, Platt, J. \& Platt, H. (1992). Longman dictionary of language teaching and applied linguistics. Harlow: Longman

Thornbury, S. (2005). How to teach speaking. Essex: Pearson Education Limited.

Wenden, A. \& Rubin, J. (1987). Learner strategies in language learning. New York: Prentice Hall.

Zare, Pezhman. (2005). WorldView level 1-4: video/dvd speaking rubric for fluency activities". Pearson Education, Inc.

Zare, Pezhman. (2012). Language learning strategies among efl/esl learners: a review of literature. International Journal of Humanities and Social Science, Vol. 2, No.5, 162-169. 